\title{
Halal Food Sustainability between Certification and Blockchain: A Review
}

\author{
Christian Bux ${ }^{1(D)}$, Erica Varese ${ }^{2, *(D)}$, Vera Amicarelli ${ }^{1}(\mathbb{D})$ and Mariarosaria Lombardi ${ }^{3}(\mathbb{D})$ \\ 1 Department of Economics, Management and Business Law, University of Bari Aldo Moro, 70124 Bari, Italy; \\ christian.bux@uniba.it (C.B.); vera.amicarelli@uniba.it (V.A.) \\ 2 Department of Management, University of Turin, 10134 Turin, Italy \\ 3 Department of Economics, University of Foggia, 71121 Foggia, Italy; mariarosaria.lombardi@unifg.it \\ * Correspondence: erica.varese@unito.it
}

Citation: Bux, C.; Varese, E.; Amicarelli, V.; Lombardi, M. Halal

Food Sustainability between

Certification and Blockchain: A

Review. Sustainability 2022, 14, 2152.

https://doi.org/10.3390/su14042152

Academic Editor: David Abler

Received: 12 January 2022

Accepted: 11 February 2022

Published: 14 February 2022

Publisher's Note: MDPI stays neutral with regard to jurisdictional claims in published maps and institutional affiliations.

Copyright: (c) 2022 by the authors. Licensee MDPI, Basel, Switzerland. This article is an open access article distributed under the terms and conditions of the Creative Commons Attribution (CC BY) license (https:// creativecommons.org/licenses/by/ $4.0 /)$.

\begin{abstract}
Islam is the second-largest religion on a global scale. All around the world Muslims are estimated to comprise more than 1.9 billion people. Therefore, the demand for Halal commodities is expected to reach a high growth rate: thus, it is crucial to increase its global market's reliability and traceability. Based on these grounds, the scope of this paper is to assess Halal food sustainability, examining the barriers and opportunities offered by the certification and blockchain tools. To this purpose, the authors carried out an integrative literature review, selecting 54 contributions in the Web of Science platform. Despite several limitations, such as the lack of a standardized framework or universally accepted and reliable certifying authorities, the implementation of blockchain technology has emerged as an interesting instrument to increase the trustworthiness and traceability of Halal foods. This tool could also help the development of protocols and standard procedures, ensuring hygienic and permitted products that may boost food safety and security. Besides, the enhancement of the Halal certification and the blockchain tool, even if several efforts are required in terms of innovation and cooperation by local authorities, industrial associations and leading consumers, could enhance fair trade, ethical business, green animal breeding and environmental economics, and hence sustainable development.
\end{abstract}

Keywords: halal food products; certification; blockchain; food safety; sustainability; integrative literature review; PRISMA model

\section{Introduction}

"Halal" is an Arabic word which means lawful or permitted according to Islamic principles, whereas the contrary is "Haram", which defines what is forbidden. Such a word is used not only in the context of commodities consumption or production but also refers to a wider range of human activities, influencing all aspects of Muslim daily life. In the context of Halal commodities and services, religious beliefs and cultural identity play a significant role in people's lifestyles and habits. Specifically, among other professed faiths, Islam imposes a precise living code which affects Muslims' everyday decisions, from food consumption habits to financial investments. Indeed, Islam requires Muslims to preserve their purity, their mentality and to maintain their self-respect and integrity under social, economic and religious perspective. As a consequence, all Muslims choices are influenced (or conditioned) by specific words, which are Halal (lawful), Haram (unlawful) [1,2] and "Mushbooh" (uncertain) [3]. Halal goods and services appeal and interest are growing fast because of strong escalation of Muslims' distribution on a global scale, so there are new challenges in terms of social integration and economics, as well as innovative challenges to increase already existing market shares and enter completely new marketplaces. Under the demographic perspective, Muslims' growth and emigration flows in the last sixty years have been impressive [4]. The latest statistics [5,6] have estimated more than 1.9 billion Muslims all around the world, making Islam the second most widespread religion 
in the world behind Christianity. In addition, the number of babies born to Muslims is expected to exceed births to Christians and Muslims have higher fertility rates than other religions. Therefore, Muslims are estimated to double by 2060, supporting the expectations of achieving roughly 3 billion believers (i.e., $31 \%$ of the expected global population) included among the "young generation" category (only $16 \%$ of consumers over 60 years old by 2050) [7-9].

In light of these premises, several economics and social considerations could be hypothesized in the field of future generations' consumption on a global scale. In the next few years, global economics must face industrial challenges in terms of commodities' production and services' provisions, considering the spreading gap between $\mathrm{Z}$ generation digitalized needs and silver generation ones $[9,10]$. Young Muslim people could play a significant role in addressing novel paths for good and services production and consumption, considering the sharp increase in demand for Halal commodities (i.e., food, clothes, pharmaceuticals, cosmetics) and services (i.e., food services, finance, tourism). One of the first opportunities for companies, in the light of Muslims migration and expected increased spending capacity, is related to the chance to penetrate lucrative markets outside Muslim home countries [11,12], leveraging on non-Muslim consumers which associate Halal products with safety and wholesomeness. The underutilized global market (i.e., the opportunity of producing Halal products by non-Muslims companies) is still growing at a higher pace. Further, considering young generations as "healthy carriers" of inspiration and being more open to change, the increase in Halal food consumption could help in reaching sustainable development goals, its products being based on biologic agriculture, fair trade, green animal breeding and environmental economics. However, the lack of standardized safety, hygiene and products healthiness certification could lead young consumers to lose faith and interest in Halal commodities, therefore determining a reduction in their demand and a possible risk of market failures. In addition, considering the spread of the COVID-19 pandemic all around the world, it seems essential to consider possible effects affecting (positively or negatively) the Islamic economy. COVID-19 pandemic consequences have been estimated in a decrease of $8 \%$ of the current market value [9]. However, it is too early to assess the precise impacts and market-related implications.

In this context, and considering the need to address new sustainable food production and consumption paths, the authors decided to focus specifically on Halal foods, analyzing the barriers and the opportunities offered by the implementation of certification systems and blockchain technology to guarantee their sustainability on the global markets. To this end, an integrative literature review and the PRISMA model to select and collect data have been applied. This review approach allows us to combine perspectives and insights from different fields or research traditions for developing new preliminary conceptualizations and theoretical models. Indeed, the authors investigate possible pathways to tackle the issue, considering several limitations such as the lack of a standardized Halal framework, or the absence of commonly accepted and reliable Halal certifying authorities [4].

In the light of emerging traceability systems and technologies to improve food supply chain management and sustainability, the present research tries to answer a novel research question, as follows: Can certification and blockchain technology enhance the reliability, traceability and sustainability of Halal foods? Blockchain technology, defined as a decentralized and transparent peer-to-peer distributed database secured by cryptography, could open protocols and standard procedures, guaranteeing either food safety or food security, and clean, hygienic and lawful food products. The present research aims to demonstrate that certification and blockchain, despite several challenges related to innovation and cooperation among authorities, industrial associations and customers, could enhance the environmental, social and economic sustainability of Halal foods, assuring fair trade, green animal breeding, environmental economics and ethical business. 


\section{Theoretical Background}

Although Halal commodities are usually related to food products, the Halal industry is not limited to agribusiness. Indeed, several key sectors could be related to the Halal industry, namely: (i) food service; (ii) consumer commodities; (iii) financial services; (iv) pharmaceutical commodities; (v) cosmetic products; (vi) logistics; (vii) tourism. Table 1 illustrates the market size for either commodities or services.

Table 1. Muslim Spend associated to the main real economy sectors.

\begin{tabular}{|c|c|c|c|}
\hline \multicolumn{4}{|c|}{ Muslim Consumers Global Expenditure (Million USD) } \\
\hline & 2012 & 2019 & $\Delta 2012-2019(\%)$ \\
\hline \multicolumn{4}{|l|}{ Commodities (or goods) } \\
\hline Foods & 1088 & 1170 & +7.01 \\
\hline Fashion & 224 & 277 & +19.13 \\
\hline Pharmaceutical & 70 & 94 & +25.53 \\
\hline Cosmetics and personal care & 26 & 66 & +60.61 \\
\hline \multicolumn{4}{|l|}{ Services (or activities) } \\
\hline Media, food service & 151 & 222 & +31.98 \\
\hline Tourism and travels & 137 & 194 & +29.38 \\
\hline Total & 1696 & 2023 & \\
\hline
\end{tabular}

Considering the Islamic perspective, Halal and Haram goods have divine origins (i.e., Qur'an and Sunnah). The Qur'an states that the designation of Halal or Haram commodities and activities (e.g., services, tourism, investments) derive from Allah, which forbids impurity and harmfulness [14] and suggests, although posing the "question of true faith", safe and healthy lifestyles. As emerged by Laluddin et al. [15] research, Halal goods could be universally applicable regardless of race, faith or gender, opening scenarios for market opportunities on a global scale, and not only among Muslims.

Halal commodities and services are based on different general principles, as follows: (i) permissibility of things, which is to say that nothing would be considered as Haram without having a direct basis for its prohibition in the Qur'an and Sunnah (i.e., principle of legality); (ii) unclean and harmful commodities are the basis for prohibition; (iii) for each prohibited commodity, Islam proposed healthy and safe alternatives (e.g., wool, linen or cotton ferment instead of silk ones); (iv) all activities and services related to Haram commodities must be considered Haram; (v) prohibition of "haramwashing" (i.e., parallel of the "greenwashing"), which consists of communication or marketing strategies pursued by companies, institutions or entities that present their activities as haram and lawful, trying to hide prohibited commodities; (vi) good intentions do not make forbidden things lawful; (vii) uncertain commodities or activities must be avoided. The latest statistics [9] have assessed the 2019 Islamic economy in more than USD 2.02 trillions spent by 1.9 billion Muslims, to which USD 2.88 trillion dollars must be added in terms of Islamic finance assets. Among others, the Halal food sector accounts for more than $57 \%$ of global Halal expenditure, attracting investments for more than USD 5.5 ( $52 \%$ of total amounts invested). Such a number of investments have been addressed by the increasing interest in Halal products by several non-Muslims countries, either for Muslim or non-Muslim consumers. Halal foods are expected to increase in popularity among non-Muslim consumers since they are supposed to be of the highest quality, healthier and safer than traditional meals [16], specifically meat and meat-based products under moral and ethical perspective (e.g., higher human animal treatments at slaughterhouses).

As far as the Halal services are concerned, Muslim travel and tourism are underevaluated, therefore unexploited. As stated by Al-Ansi [17], Muslims are considered to be top spenders among other international travelers and, by 2026, the Halal travel and 
tourism sector is expected to increase up to USD 300 (35\% more than 2019 levels) [18]. However, to achieve a "Muslims friendly tourism", which connects Halal foods, genderrelated distinction, facilities or prayer and leisure activities in line with Islamic law, several strategies in the field of hospitality and food service industry are required $[19,20]$. Halal commodities and services could be appreciated not only under social (i.e., improvement of Muslims integration within non-Muslims countries) or economic (i.e., increase in market shares) perspectives, but also in terms of sustainable implications, as it is possible through Halal food products to reduce global greenhouse gas emissions and liquid and solid waste generation [21]. As defined by Talib [22,23], Halal commodities and Halal foods tend to enclose biologic agriculture, fair trade, green animal breeding and environmental economics, encompassing those paradigms of environmental sustainability and corporate social responsibility. Then, Halal food guidelines/standard and non-Halal food supply chain standards, in terms of environmental protection requirements, seem to coincide in more than one circumstance (e.g., organic production) [24,25]. Therefore, Halal green production could represent an opportunity towards energy, water, land and natural resources optimization, reducing global environmental emissions. In terms of Halal products, Statista [5] reveals that meat and meat derivatives (52\%), were the most consumed foods worldwide in 2019, followed by milk and milk products $(16 \%)$, grain, fruits and vegetables $(14 \%)$, with quite similar trends in the next ten years. In terms of the number of Halal product launches with Halal claims in recent years, more than 288 products were released in France, over 223 in Turkey and approximately 158 in the United Kingdom, while only 21 in the Italian market [6].

Currently, the COVID-19 pandemic represents a social, health and financial challenge, being one of the most worrying crises after the Second World War [26]. Such a disease has affected (and still affects) all economic and industrial sectors, negatively impacting the food sector from production to consumption, either under social (e.g., jobs) or financial perspectives (e.g., profits, revenues). Entire countries implemented singular forms of social distancing and lockdowns, upsetting life, work and daily activities among final consumers/customers/investors. In the light of the pandemic, more than 400 million permanent jobs have been lost in the Islamic market, whereas poverty rose to levels without precedent, registering extreme scenarios of consumption contractions from 10 to $20 \%$ and expecting a decrease in Muslims' expenditure by $8 \%$. In the hospitality industry, more severe falls than those recorded in food, fashion or recreation are expected, from USD 194 billion in 2019 to less than USD 58 billion in 2020 [9]. Therefore, fast-tracked digital transformations to adapt and survive, as well as novel strategies, are required, such as the adoption of meat processors (e.g., Tyson Foods) using a slaughtering robot [27]. Although dining out has been stopped and B2B food service sales have been prohibited, several food security initiatives spread, as well as e-commerce and delivery, with an increase in healthy, functional and clean label foods consumption. Further, in the field of tourism and hospitality, numerous investments have been made towards standards, safety and hygiene protocols, sustainable and domestic tourism, private and public transport, registering hotels and large accommodation-lodging facilities expanding as quarantine centers. Then, in terms of cosmetics and fashion, skincare, protection and cosmeceutical products spread, as well as green fashion and custom-made clothing. Last, concerning pharmaceutical commodities, local products, home-made healthcare commodities, vitamins and immunityboosting supplements and medical tourism have been implemented. Such a picture, even if industrial transformation and logistics have been interrupted, upsetting the global and the Islamic economy, highlights a "new economy" inspired by local manufacturing, sustainable tourism and fair, healthy and safe production/consumption behaviors. Under a geographical perspective, the leading countries are Malaysia and the United Arab States, historically based on Muslim inhabitants [9,28]. However, promising countries showing significant progress in the Halal markets are Nigeria, United Kingdom and Thailand, based on a sharp increase in credentials awareness. 


\section{Research Methodology}

\subsection{Integrative Literature Review Strategy}

Several strategies, standards and guidelines could be adopted to develop a critical literature review. Among others, the present research implements the integrative literature review approach, as defined by Snyder [29]. It helps in mapping and developing a specific research field over time, building novel theories and highlighting opportunities. In line with previous researchers [30,31], an integrative literature review assesses, evaluates and synthesizes literature according to emerging perspectives. Therefore, the present study discusses the adoption of certification and blockchain to improve Halal food sustainability. Further, it aims at collecting data in a more creative manner, not covering all articles published in a specific research field, rather combining original perspectives and insights coming from different research areas [29,32]. As for reaching trustworthiness and scientific soundness, the authors have adopted a stepwise approach, as follows: (a) design; (b) conduct; (c) analysis; and (d) structuring and writing [29].

The analysis has been managed on Web of Science (WoS), considered as an adequate database of consistent and dependable research [33], in the last twenty years (2001-2021). Concerning review criteria, the authors have considered only academic peer-reviewed articles written in English, without accounting for book chapters or proceeding papers. Further, additional contributions have been chosen on the basis of existing knowledge, experts' suggestions and chance during research. From a geographical perspective, stating the high diffusion of Muslims and Halal certification authorities on a global scale, all countries have been considered, from developed to developing areas. In the light of the research question (i.e., Can certification and blockchain technology enhance the reliability, traceability and sustainability of Halal foods?), and considering the need to enhance Halal certification and food sustainability, several research keywords were selected. To integrate the concepts of Halal certification, blockchain and sustainability, the subsequent keywords' combinations were considered: "halal" or "halal food" AND "certification" or "blockchain" or "sustainability" in the abstract or keywords, according to a TITLE-ABS-KEY query.

\subsection{Data Collection and Analysis}

Meta-data have been catalogued in Microsoft Excel according to the authors' names, articles' titles, language, the type of document (i.e., research article, review article, proceeding paper), authors' keywords, abstract, authors' addresses, times cited, publishing journal, year of publication, doi (i.e., digital object identifier) and research area. Successively, this wide range of meta-data has been reported in a PRISMA diagram, able to account for an evidence-based minimum set of items (Figure 1). Indeed, the records have been identified, selected and analyzed to assure their eligibility for the integrative literature review [34]. This has meant, for example, to remove duplicates and screen them for relevance. The use of such a model allows substantial transparency and trustworthiness in the selection process of published articles [35].

Then, data were analyzed based on a content analysis [36], and significant keywords and research clusters were depicted according to a co-word analysis. Such research keywords were investigated through the software VOSviewer, which allows us to create, visualize and explore maps based on bibliometric networks. It highlights items (i.e., keywords) and links between keywords [37], and provides a systematic overview of research trends along selected timelines, creating suggestive and clear maps of keywords [38]. It still represents a rigorous method for investigating huge amounts of meta-data [39,40]. 
Identification of studies via Web of Science

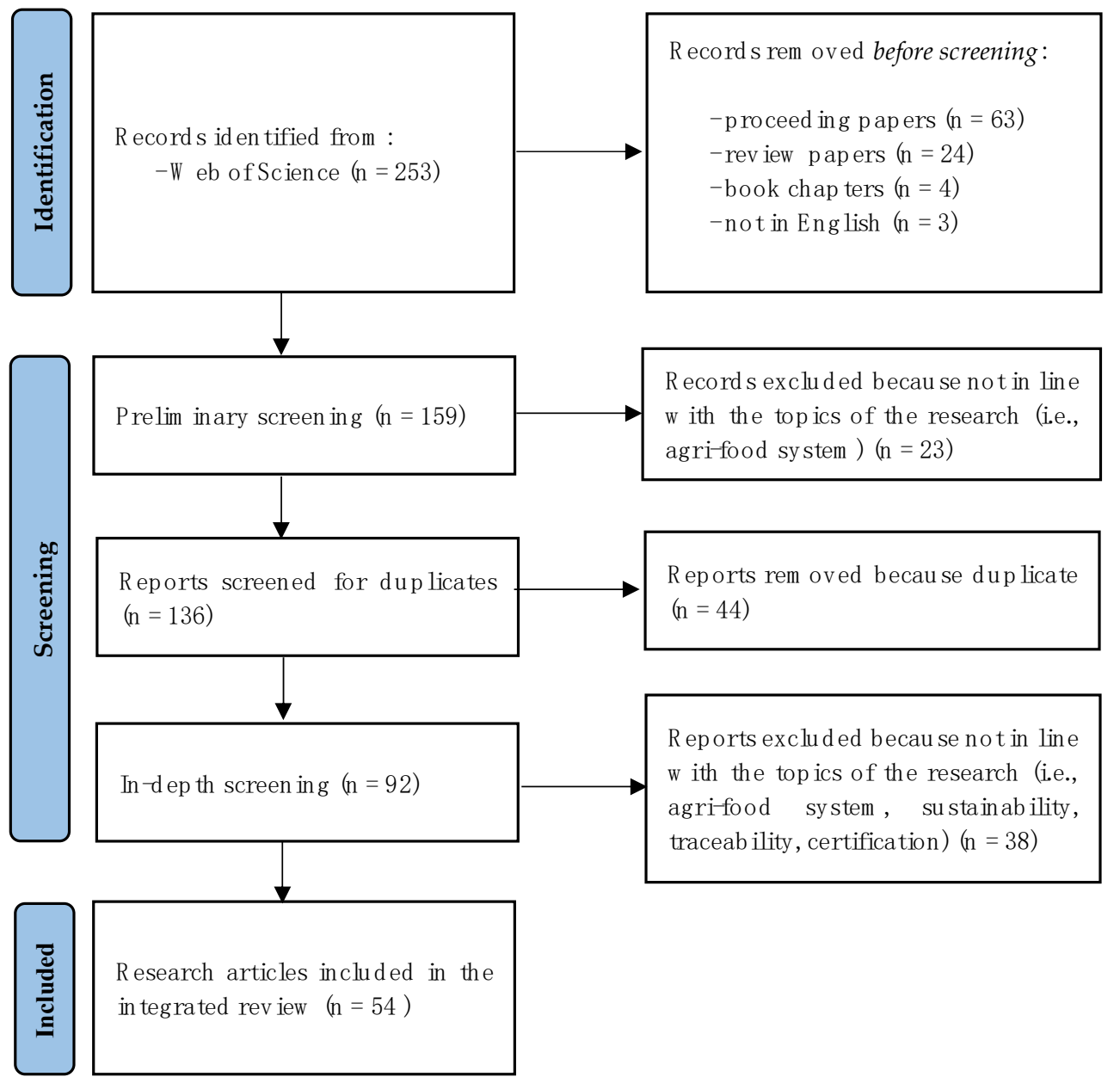

Figure 1. PRISMA Model. Source: Personal elaboration by the authors on Page et al. [41].

\section{Results}

As outlined by Figure 1, 253 contributions were identified on Web of Science, of which 63 proceeding papers, 24 review articles, 4 book chapters and 3 articles published in languages other than English. Several contributions were removed because not in line with the aims and scope of the research (61 articles) and others because duplicates (44 articles). Overall, 54 contributions were selected for in-depth investigations.

As to evaluate the geographical areas of the selected contributions, the authors have considered the authors' affiliation. The vast majority of investigations has been conducted by Malaysian researchers (19 contributions), followed by English ones (seven contributions). On the other hand, few but significant articles were published by Indian, Indonesian, American, Japanese and Italian researchers, highlighting the great interest in investigating Halal certification, blockchain and sustainability. In terms of journals, 15 articles were published by the Journal of Islamic Marketing (Emerald Insight), followed by six contributions in the British Food Journal (Emerald Insight) and three either in the Food Control (Elsevier) or in the Trends in Food Science and Technology (Elsevier). On the side of the research areas, three main clusters could be identified: (a) business and economics, with 27 contributions; (b) food science and technology, with 13; and (c) agriculture, with 11. It is interesting to depict that several articles belong to more than one research area, highlighting the high transversality of the Halal issue (e.g., agriculture and history; anthropology and religion, geography and public administration). In terms of publishing timeline, the first contribu- 
tion dates back to 2007 [42], but all the other articles were published between 2012 (three articles) and 2021 (eight articles). The highest peak was registered in 2016 (11 contributions) and 2019 (ten contributions).

The last insight concerns the three main keywords and the research trends related to certification, blockchain and sustainability. As highlighted by Figure 2, the keyword "blockchain" seems to appear starting from 2020, and it is connected with the items "technology" and "traceability", as well as with the word "management". On the other side, "certification" has been a trendy issue since 2018 and is connected with items such as "innovation", "quality", "trust", "identity" or "choice". It lies quite in the middle of the scientific landscape (i.e., VOSviewer map), highlighting its importance in the Halal research. However, the word "sustainability" seems not to appear in the landscape, being repeated only five times in the 54 selected contributions (according to a TITLE-ABS-KEY query).

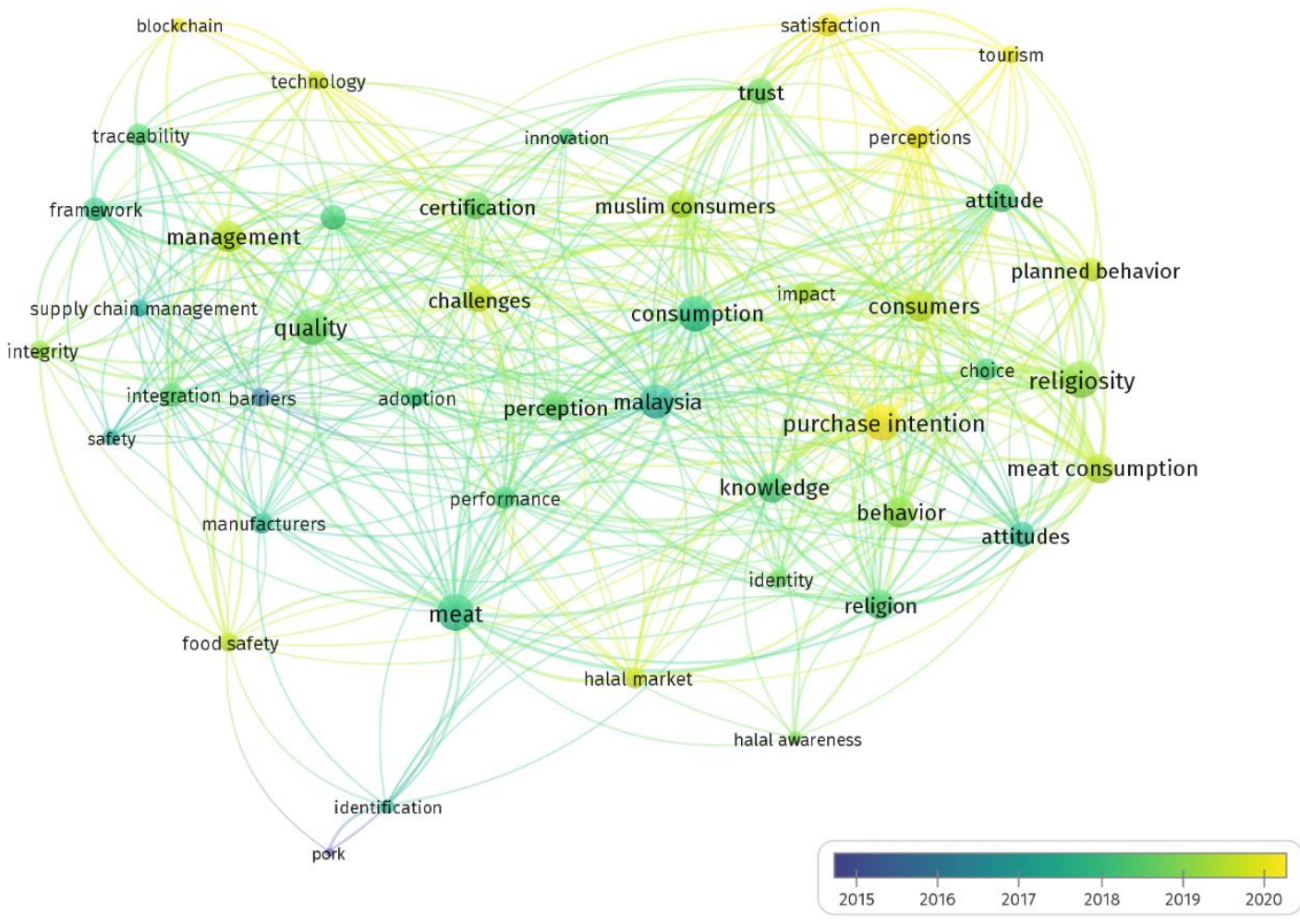

Figure 2. Keywords and research trends (through the VOSviewer software). Source: Personal elaboration by the authors.

Overall, the most cited article [43] deals with the growth Halal meat markets in Europe under either a business or religious perspective (96 citations), whereas the second most cited article [42] investigates pork derivatives in food products (85 citations).

Appendix A-Table A1 synthesized the selected contributions according to the three main research topics. Among others, the main research trends are related to certification opportunities and/or barriers, whereas few researchers have investigated blockchain technology [44-47]. In the field of Halal food sustainability, some authors [48] have explored specific sustainability measures, whereas others have highlighted the connection between agricultural best practices and Halal development [49] or the need to enhance Halal sustainable tourism [50]. Interesting insights were provided by Randeree [51] and Nisha and Iqbal [52] in the field of "halal ecosystems". Last, it should be depicted that several authors have investigated the Halal meat industry, either in terms of pork, poultry or beef meat [53-55]. 


\section{Discussion}

\subsection{Halal Certification}

The increase in already existing market shares, the chance to enter completely new marketplaces and the opportunity to enhance business performances represent desirable goals either for Muslim or non-Muslim companies [56,57], even if several challenges related to certification issues must be addressed [23,58,59]. At present, several Halal food companies are multinational and based in developed countries, but several Malaysian companies are also growing, supporting governance and access to demand by certification [16,24]. Halal certification represents one of the principal variables to enter global Halal markets, considering its assurance of Qur'an and Sunnah compliances [60,61]. As stated by prior research, the Halal certification could be defined as "a food certification ingrained in the doctrines of safety, hygiene, and wholesomeness" [22,23], or as "the realm of business and trade and the global symbol for quality assurance and lifestyle choices" [62]. Therefore, being assimilable among the food safety certifications, Halal ones could be treated the same as the Good Manufacturing Practice (GMP), the Hazard Analysis and Critical Control Points (HACCP) or the Quality management certification (ISO 9000). Latest research discussed a certain urgency for its standardization [63-65], as well as a need to improve its current certification model $[66,67]$, as to meet either manufacturers or consumers' needs.

Historically, first experiences of Halal certification date back to the mid 1960s, when American Muslim food and technical specialists, tried to assure to Muslim immigrants (in non-Muslim countries) the safeguard of their spiritual beliefs, as well as to preserve their religious and cultural identity [4]. Supported by the Jewish community, at the time involved in the creation of a novel certification system defined as "kosher" and based on a strict set of dietary rules called "kashrut", the Muslim specialists designed their first Halal logo. Soon after, an ever-increasing amount of Halal certification bodies (more than one hundred on a global scale) $[68,69]$, as well as a rising number of regulation and standards (e.g., Standards and Metrology Institute for Islamic Countries, Organization of Islamic Cooperation) spread, specifically in food commodities such as meat and meat-based products, taking care of different countrywide or domestic Muslim protocols (e.g., Sunni, Shia) or responding to diverting Muslim divisions (e.g., Hanafi, Hanbali, Maliki) [68]. Then, a variety of Halal logos and certificates became widespread in the Halal markets, increasing the heterogeneity in certification procedures (e.g., lack of uniformity) and generating confusion and misunderstandings from one certificate to another, as well as from one country to another $[70,71]$. Nowadays, single states could accept specific certification authorities, without a dominant coordination at central administrative level [4]. As illustrated by Table 2, the list of authorized certification bodies, although not complete, is dense and constantly changing. However, a few insights could be reported. For instance, Algeria has created a unique national collective brand owned by the Algerian Standardization Institute (IANOR, Algeria), developed on the basis of the Organization of Islamic Cooperation (OIC, Kingdom of Saudi Arabia) standards and on the Standards and Metrology Institute for Islamic Countries (SMIIC, Turkey). Such an approach has been adopted to enhance the Algerian economy through the creation of a Halal national trademark, as well as to increase the international recognition of Algerian companies in "explaining the halalness" of their products [69]. On the contrary, non-Muslim countries such the United States of America and Australia encompass approximately 14 and 24 authorized certifying bodies, respectively, illustrating how the interest in centralizing the certification of Halal products in a single body mostly belongs to Islamic countries. It is possible to outline that the higher the number of Muslims in a country, the greater the centralization of the Halal certification in a single body (e.g., Algeria, Morocco, Sudan). 
Table 2. Halal certification bodies on global scale in 2021 .

\begin{tabular}{|c|c|c|c|}
\hline Region & Country & Muslims (\%) & ACB \\
\hline \multirow{7}{*}{ Africa } & Algeria & $99.00 \%$ & 1 \\
\hline & Morocco & $99.00 \%$ & 1 \\
\hline & Sudan & $95.00 \%$ & 1 \\
\hline & Egypt & $90.00 \%$ & 3 \\
\hline & Nigeria & $53.50 \%$ & 2 \\
\hline & Cameroon & $20.90 \%$ & 1 \\
\hline & South Africa & $1.90 \%$ & 4 \\
\hline \multirow{2}{*}{ North America } & Canada & $3.20 \%$ & 10 \\
\hline & United States & $0.90 \%$ & 14 \\
\hline \multirow{2}{*}{ South America } & Brazil & $0.01 \%$ & 2 \\
\hline & Argentina & $0.01 \%$ & 2 \\
\hline \multirow{15}{*}{ Asia } & Kingdom of Saudi & $99.00 \%$ & 1 \\
\hline & Pakistan & $96.40 \%$ & 7 \\
\hline & Uzbekistan & $88.00 \%$ & 1 \\
\hline & Brunei & $80.90 \%$ & 1 \\
\hline & Malaysia & $61.30 \%$ & 1 \\
\hline & Singapore & $14.70 \%$ & 1 \\
\hline & India & $14.20 \%$ & 8 \\
\hline & Russian Federation & $10.00 \%$ & 3 \\
\hline & Philippines & $10.00 \%$ & 1 \\
\hline & Sri Lanka & $9.70 \%$ & 1 \\
\hline & Thailand & $4.30 \%$ & 1 \\
\hline & Hong Kong & $4.10 \%$ & 1 \\
\hline & Taiwan & $0.30 \%$ & 1 \\
\hline & Vietnam & $0.10 \%$ & 1 \\
\hline & Japan & $0.10 \%$ & 3 \\
\hline \multirow{12}{*}{ Europe } & Turkey & $89.50 \%$ & 2 \\
\hline & Bosnia Herzegovina & $50.70 \%$ & 1 \\
\hline & France & $8.00 \%$ & 5 \\
\hline & Austria & $8.00 \%$ & 2 \\
\hline & Belgium & $7.60 \%$ & 1 \\
\hline & United Kingdom & $6.30 \%$ & 3 \\
\hline & Denmark & $5.40 \%$ & 1 \\
\hline & Netherlands & $5.10 \%$ & 2 \\
\hline & Germany & $5.00 \%$ & 13 \\
\hline & Italy & $4.80 \%$ & 1 \\
\hline & Spain & $2.60 \%$ & 1 \\
\hline & Poland & $0.10 \%$ & 1 \\
\hline \multirow{2}{*}{ Oceania } & Australia & $2.60 \%$ & 25 \\
\hline & New Zealand & $0.90 \%$ & 2 \\
\hline
\end{tabular}

Notes: ACB = Authorized Certifying Bodies. Source: Personal elaboration by the authors on $[7,67,72]$.

The achievement of Halal certification is a composite procedure composed of different internal audits from agricultural production to industrial transformation, logistics and distribution [73], whose aim is to guarantee that commodities and services fulfill the Halal requirements [74,75]. In technical terms, the certifying organization carries on an evaluation of the entire manufacturing procedure, exploring either natural resources or food components [76]. Further, considering that only manufacturers can request the certification process, several concerns are related to its difficulty and time-consuming operations. As regards Halal certification among restaurants, several challenges are related to time-consuming activities, the paperwork being too complicated, the short period of certification and high certification fees, which make entrepreneurs' commitment even more scarce [77].

At present, several limits have been identified on the side of Halal certification, most of which are related to the complexity of global markets, as well as to the offshoring of 
the various production plants, which make mapping and controls increasingly difficult at the logistical level $[67,78,79]$. Considering the food chain, Halal-certified products require planning, enhancement and monitoring from upstream to downstream stages [80]. Under the drivers' perspective, several variables should be brought back to frauds and commodities' physical contamination, as well as to uncertain products traceability [81], which make documents not reliable at all. Moreover, as proposed by prior research [61], other barriers towards capable and guaranteed Halal certification are linked to the absence of: (a) manufacturers and customers' perception in terms of hygiene, pureness, safety and quality [59]; (b) Halal-certification authorities to meet the large scale demand; (c) research and development, as well as infrastructures and funds to increase and safeguard commodities' freshness; (d) universally accepted Halal certifying authorities, due to the high number of certification bodies, as well as their unexploited cooperation towards single standardizes and simplified processes [81]; (e) corruption among certifying authorities [82,83].

One of the main drivers towards Halal supply chains' success relies on the efficient and adequate certification system, and several benefits could be related to efficient certification processes. Under the benefits perspective, it is fundamental to distinguish among in-house advantages (i.e., economic, logistics, human resource benefits) and outer ones (i.e., loyalty with stakeholders, market reputability, competitive edge) [73]. However, from a financial perspective, entering the Halal markets could enhance sales and revenues, simultaneously reducing direct and indirect costs due to non-quality products (e.g., loss of consumer loyalty, return of goods, products defects). Furthermore, the enhancement in Halal certification is more likely to return high standards of food safety and food hazard control, letting firms reach higher levels of competitiveness within already competitive markets by reducing the asymmetric information among manufacturers and customers [84]. In terms of human resources, Halal certification could engage employees, increasing their motivation, refining their awareness and cultivating their culture of quality and safety, as well as creating a healthier work environment $[85,86]$. Lastly, under the consumers' perspective, Psomas et al. [87] have estimated Halal certification opportunities in boosting positive consumers' feelings for food companies, enhancing brand loyalty and satisfaction through better images and reputation.

Halal foods have positive effects both on physical and psychological health, being a good alternative either for Muslim or non-Muslim consumers. As concerns the Islamic slaughtering techniques and the removal of harmful blood, Halal meat and meat-based products are more likely to meet food safety national and international targets $[42,54,88]$. Meanwhile, alcohol, as a depressant to the nervous system, causes shrinks to a high extent and leads to senility; its absence within Halal products can reduce such risks [89]. Halal foods can act as carriers for positive effects in the field of human development, either under moral, intellectual and psychological perspectives.

\subsection{Halal Blockchain}

The current Halal certification model requires several attempts to reach a total protection of food safety and healthy lifestyles, considering its malfunctioning under social (e.g., waste of time, uncertain commodities) and financial (e.g., expensive processes) perspectives. As analyzed by De Boni and Forleo [12], some barriers are still affecting domestic markets, for instance the scarce familiarity with Halal commodities and activities, the lack of trust towards the Islamic background and the expensive costs of Halal-certified products (compared to not certified products). Further, customers and manufacturers ask for more data with reference to natural resources and raw materials sources, technologies applied and transparency with regards to Halal standards and certification bodies, considering the existing confusion about applicable standards among manufacturers.

Several opportunities to increase Halal food reliability and traceability could regard the adoption of the blockchain technology, which makes it possible to boost commercial opportunities by adopting open protocols and standard procedures [90]. Overall, this technology can facilitate the certification process according to its scrupulous structure, 
which consists of: (i) block, containing data and transaction lists; (ii) chains, linking block through cryptography; (iii) transactions, changing blocks [91]. Such as tool, defined as "a public ledger consisting of all transactions taking place across a peer-to-peer network" [92], can be described as a decentralized and transparent peer-to-peer distributed database secured by cryptography, where transactions are registered in a constantly growing list of records, also called a "chain of records", which are immutable and append-only. Records can be updated through specific agreements among peers, and untrusted transactions are not agreed and not included in the chain [93,94]. The first attempts of blockchain technology were addressed to support the cryptocurrency trade, but later such technology has been introduced to store all information related to several commodities and service sectors, such as automotive, banking and finance, healthcare, life sciences, manufacturing and agribusiness [95]. The blockchain has been applied with success, even in education, privacy and security, as well as in governance (e.g., notary, law). Among its goals, it is aimed at increasing transparency and visibility for all stakeholders from agricultural production to distribution and final consumption stage. Through its application, all raw materials suppliers, manufacturers, distributors, wholesalers, retailers and final consumers increase their chance to store all transactions and obtain a (quite) complete guarantee on the trustworthiness of products and contacts. Blockchain records procedures and makes documents unalterable, providing certification cost savings from 70 to $90 \%$ [96], but some efforts from local governments, industrial associations and dominant customers are needed. Figure 3 illustrates the input flows which must be traced and tracked from agricultural production to final consumption stage. The blockchain technology can be accessed by any of the supply chain actors, but none of them can modify the succession of the information shared among all nodes in the system. It means that the history of the network is immutable [91].

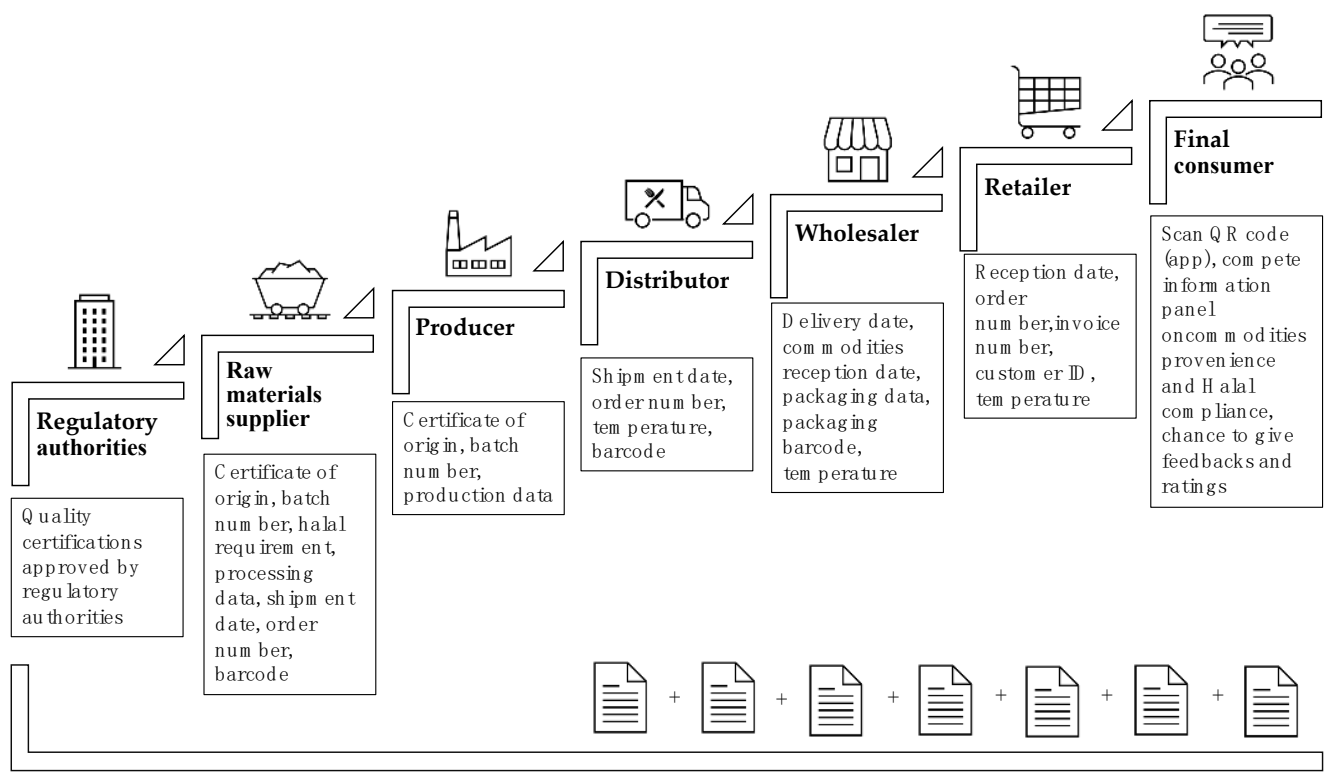

Figure 3. Input Flows Along the Food Supply Chain. Source: Personal elaboration by the authors.

As stated by reference literature [47,97], blockchain technology can foster the Halal food sector, by ensuring digitalization of Halal certificates, and assure full-scale Halal integrity to consumers. Among others, it could open four different opportunities to smallmedium food enterprises, as follows: (a) reduction in complexity and increase in capability; (b) reduction in costs and increase in competitive advantage; (c) development in change management and reduction in external pressure; and (d) adoption of Halal sustainable production and consumption. 
In this latter field, the blockchain could reduce food safety risks and increase social benefits by enlarging information related to pesticides or fertilizers, and by enhancing the use of "sustainability certificates" [98]. Surjandari et al. [46] have tested the capabilities of a Blockchain Network in the field of Halal development, estimating the utility of such a tool in securing transactions from food safety risks, and speeding and rating transactions in an effective and transparent manner. However, its adoption in small-medium food enterprises requires huge financial investments and resources, which can prevent entrepreneurs from participating in blockchain-based Halal traceability programs. As a consequence, Hew et al. [45] has stressed the role of policymakers in encouraging the participation in blockchain programs by giving tax incentives.

At present, the blockchain as a tool to ensure food safety and food security has been recently included in the Foodwatch [99] platform, namely a platform aimed at enabling modernization and digitization of all aspects of municipalities' food safety management. Such a platform manages and distributes food safety information, as well as nutritional information, among stakeholders (both private and public), and it is based on blockchain, smart contracts, artificial intelligence, big data analytics, end-to-end traceability and recall management. An additional opportunity to guarantee that companies meet Halal standards is represented by the traceability software implemented by the Global Food Safety Resource (GFSR) strategy for specialty food products. As proposed by Burton [100], the food traceability software replaces the paper-based system with electronic data collection and record keeping. Data are collected through hand-held devices, and cloud-based systems automatically create the suitable report. The adoption of automated technologies (i.e., Internet of Things, IoT) represents a necessity of companies (and food companies) all around the world, since properly planned and applied food safety programs ensure sources of ingredients and amplify the adherence to regulations. As a consequence, the adoption of IoT technologies makes preparation for audits and inspections easier, removing those barriers related to binders and spreadsheets collection.

\subsection{Sustainability in Halal}

Some authors $[48,101]$ have stated that sustainable practices are integrated in the Halal food supply chain, considering the need to guarantee food safety, hygiene, equality, fair trade and animal welfare from farm to fork. Indeed, this supply chain, under a social, environmental and economic perspective, encompasses good manufacturing and agricultural practices, as well as hazard analyses [50,102]. One of Halal sustainability's greatest strengths is related to the adoption of processing methods which eliminate poisonous, intoxicating and hazardous elements from Halal foods [47]. In the field of good agricultural practices, Alzeer et al. [49] states that a safety plan based on such practices (i.e., processes, ingredients and their sources must be traceable, clearly defined and controlled, and instructions must be written in a clear language) should be recognized as a prerequisite for obtaining a Halal certificate, creating a win-win situation either for producers or the consumers' needs. On the producers' side, the adoption of these practices can enhance competitive advantage through the development of sustainable strategies and environmental protection; whereas on the consumers' side it could increase trust, enrich cultural diversity and build bridges between countries, religions and traditions [49]. Further, Halal sustainability should be pursued by enhancing infrastructures to avoid physical contact with non-Halal products, as well as the management commitment from top management to employees. It emerges that sustainable procedures and good agricultural practices are closely related to the adoption of information and telecommunication technologies, which enable traceability and products' authenticity, highlighting the need to enhance blockchain technology [103]. To this extent, the blockchain could help farmers and manufacturers in reducing chemical inputs, fertilizers and hazardous elements [47]. However, as already discussed by the European Environmental Agency [92], the environmental and sustainability implications of this technology are under-explored, and still experiments to obtain data and monitoring to assess reliability are required on a global and local scale. 
Regarding additional research in the field of Halal sustainability, Thamagasorn and Pharino [104] have explored the food waste issue in a Halal food production process, confirming that these products have been increasingly responding to market pressures coming from environmental movements, and enhancing environmental performances by creating value-added compounds from waste materials [104,105]. Mixed approaches based on mass-balance methods (i.e., material flow analysis) and blockchain technology could enhance food waste valorization towards sustainable practices and environmental savings [106] in the Halal food sector. As reported by Rejeb et al. [106], digital food supply networks based on the blockchain could enable full transparency across the food supply chain and maximize shelf life, increase partnerships and enhance recall response efficiency.

\section{Conclusions}

Halal foods and services are expected to grow at a high rate, reaching unpredicted production and consumption levels both in Muslim and non-Muslim countries, considering their proximity to biologic agriculture, fair trade, ethical business, green animal breeding and ecological economic paradigms, as well as to environmental sustainability and corporate social responsibility. However, it is necessary to increase the efficiency of their certification systems as well as to introduce new technologies in each step of the supply chain to boost their sustainability.

The enhancement of Halal certification, indeed, could make Halal industry trusted all around the world. Concerning the agribusiness, it could lead to global standards of food quality and ethics, nowadays required either by European or International authorities, favoring either producers or consumers. On the side of the former, certified foods might easily reach worldwide markets and enter new segments as well as benefit from experts, scholars and inspectors along the entire certification period, enhancing at the same time economic (e.g., improved profits) and social (e.g., improved trust) sustainability. As regards consumers, people can take advantage from a peaceful state of mind, considering the assurance on the purchased products and the guarantee on the ingredients and raw materials, towards food safety and food security on a global scale.

On the contrary, the adoption of new technology, such as the blockchain, certainly represents one of the main opportunities to assure the reliability, traceability and food safety to consumers. Being user-friendly, cost and time-effective, it allows improvements in capability and reduction of complexity between consumers and managers; increases the competitive advantage; and allows adoption of trusted sustainable production and consumption patterns. Further, the blockchain could foster environmental and social sustainability, helping farmers and manufacturers in reducing chemical inputs, fertilizers and hazardous elements, as well as consumers in increasing trust and cultural diversity by traceable and reliable certificates. However, the role of policymakers should be highlighted in encouraging producers' participation in blockchain programs.

The present research has highlighted barriers and opportunities towards the enhancement of Halal foods on global markets, focusing on the upstream stages of the food supply chain (e.g., agricultural stage, manufacturing, distribution). Future research directions should investigate consumers' perception of Halal certification, focusing on the role of customers as carriers of transparency, equality and trust within companies' boundaries. To this extent, the blockchain could represent an interesting instrument to retain consumers, increase safe shopping experiences and enhance secure markets.

Author Contributions: This paper should be considered the result of the common work of the four authors, as follows: Conceptualization, C.B., E.V., V.A., M.L.; investigation, C.B., V.A.; resources, C.B., V.A.; writing-original draft preparation, C.B.; writing-review and editing, C.B., V.A.; supervision, E.V., V.A., M.L. All authors have read and agreed to the published version of the manuscript.

Funding: This research received no external funding.

Institutional Review Board Statement: Not applicable. 
Informed Consent Statement: Not applicable.

Conflicts of Interest: The authors declare no conflict of interest.

\section{Appendix A}

Table A1. Data Synthesis (54 Selected Articles).

\begin{tabular}{|c|c|c|c|c|}
\hline Reference & Research Item & Certification & Blockchain & Sustainability \\
\hline Ali et al., 2021 & Sustainable Blockchain Framework & & $\checkmark$ & $\checkmark$ \\
\hline Muneeza and Mustapha, 2021 & Halal Fisheries & $\checkmark$ & & \\
\hline Secinaro et al., 2021 & Corporate Social Responsibility & $\checkmark$ & & \\
\hline Khan et al., 2021 & Sustainability Measures & & & $\checkmark$ \\
\hline Surjandari et al., 2021 & Permissioned Blockchain Network & & $\checkmark$ & \\
\hline Ali et al., 2021 & Food Quality Performance & $\checkmark$ & & \\
\hline Lestari et al., 2021 & Performance Measurement & $\checkmark$ & & \\
\hline Wannasupchue et al., 2021 & Halal Restaurants & $\checkmark$ & & \\
\hline Hew et al., 2020 & Traceability Systems & & $\checkmark$ & \\
\hline Tan et al., 2020 & Traceability Systems & & $\checkmark$ & \\
\hline Haleem, 2020 & Certification Opportunities/Barriers & $\checkmark$ & & \\
\hline Alzeer et al., 2020 & Agricultural Best Practices & $\checkmark$ & & $\checkmark$ \\
\hline Rahim et al., 2020 & Halal Talents Sustainability & & & $\checkmark$ \\
\hline Tayob, 2020 & Ethical Practices & $\checkmark$ & & \\
\hline Nuratifah et al., 2019 & Certification Opportunities/Barriers & $\checkmark$ & & \\
\hline Khan et al., 2019 & Certification Opportunities/Barriers & $\checkmark$ & & \\
\hline Thamagasorn and Pharino, 2019 & Halal Food Waste & & & $\checkmark$ \\
\hline Ahmed et al., 2019 & Consumers Behavior & $\checkmark$ & & \\
\hline Randeree, 2019 & Halal Food Ecosystems & $\checkmark$ & & $\checkmark$ \\
\hline Vanany et al., 2019 & Halal Meat Industry & $\checkmark$ & & \\
\hline Salindal, 2019 & Certification Opportunities/Barriers & $\checkmark$ & & \\
\hline De Boni and Forleo, 2019 & Certification Opportunities/Barriers & $\checkmark$ & & \\
\hline Takeshita, 2019 & Certification Opportunities/Barriers & $\checkmark$ & & \\
\hline Jalil and Qamar, 2019 & Halal Meat Industry & $\checkmark$ & & \\
\hline Ahmad et al., 2018 & Halal Control System & $\checkmark$ & & \\
\hline Sayogo, 2018 & Online Traceability & $\checkmark$ & & \\
\hline Ahamat and Rahman, 2018 & Halal Meat Industry & $\checkmark$ & & \\
\hline Ali et al., 2017 & Halal Assurance System & $\checkmark$ & & \\
\hline Abd Rahman et al., 2017 & Halal Assurance System & $\checkmark$ & & \\
\hline $\mathrm{Ab}$ Talib et al., 2017 & Certification Opportunities/Barriers & $\checkmark$ & & \\
\hline Kurth and Glasbergen, 2017 & Muslim Identity & $\checkmark$ & & \\
\hline Fujiwara, 2017 & Certification Opportunities/Barriers & $\checkmark$ & & \\
\hline Kubota et al., 2017 & Certification Opportunities/Barriers & $\checkmark$ & & \\
\hline Nisha and Iqbal, 2017 & Halal Ecosystems & $\checkmark$ & & $\checkmark$ \\
\hline Ab Talib et al., 2016 & Certification Opportunities/Barriers & $\checkmark$ & & \\
\hline Lubis et al., 2016 & Certification Opportunities/Barriers & $\checkmark$ & & \\
\hline Ab Talib et al., 2016 & Certification Opportunities/Barriers & $\checkmark$ & & \\
\hline White and Samuel, 2016 & Certification Opportunities/Barriers & $\checkmark$ & & \\
\hline Rafiki and Wahab, 2016 & Certification Opportunities/Barriers & $\checkmark$ & & \\
\hline Shahdan et al., 2016 & Halal Meat Industry & $\checkmark$ & & \\
\hline Othman et al., 2016 & Halal Assurance System & $\checkmark$ & & \\
\hline Borzooei and Asgari, 2016 & Consumers Behavior & $\checkmark$ & & \\
\hline Dubé et al., 2016 & Certification Opportunities/Barriers & $\checkmark$ & & \\
\hline Tayob, 2016 & Certification Opportunities/Barriers & $\checkmark$ & & \\
\hline Chanin, 2016 & Sustainable Halal Tourism & & & $\checkmark$ \\
\hline Tieman, 2015 & Certification Opportunities/Barriers & $\checkmark$ & & \\
\hline Ab Talib et al., 2015 & Certification Opportunities/Barriers & $\checkmark$ & & \\
\hline Prabowo et al., 2015 & Certification Opportunities/Barriers & $\checkmark$ & & \\
\hline Atalan-Helicke, 2015 & Certification Opportunities/Barriers & $\checkmark$ & & \\
\hline Hussein, 2015 & Certification Opportunities/Barriers & $\checkmark$ & & \\
\hline Lever and Miele, 2012 & Halal Meat Industry & $\checkmark$ & & \\
\hline van der Spiegel et al., 2012 & Certification Opportunities/Barriers & $\checkmark$ & & \\
\hline Marranci, 2012 & Certification Opportunities/Barriers & $\checkmark$ & & \\
\hline Che Man et al., 2007 & Halal Meat Industry & $\checkmark$ & & \\
\hline
\end{tabular}

\section{References}

1. Jaelani, A. Halal tourism industry in Indonesia: Potential and prospects. Int. Rev. Manag. Mark. 2017, 7, 25-34. [CrossRef]

2. Naeem, S.; Ayyub, R.M.; Ishaq, I.; Sadiq, S.; Mahmood, T. Systematic literature review of halal food consumption-qualitative research era 1990-2017. J. Islam. Mark. 2020, 11, 687-707. [CrossRef]

3. Riaz, M.N.; Chaudry, M.M. Halal Food Production; CRC Press: Boca Raton, FL, USA, 2004; pp. 1-379. 
4. Amicarelli, V.; Gallucci, T.; Lagioia, G. The Influence of Halal Certified Products in Italian Food Markets: In Commodity Science in Research and Practice-Towards Quality-Management Systems and Solutions; Sikora, T., Dziadkowiec, J., Eds.; Polish Society of Commodity Science: Cracow, Poland, 2014; pp. 7-17.

5. Statista. Distribution of Halal Food Market Worldwide in 2019 and 2028, by Product. Available online: https:/ / www.statista. com/statistics/1234004/worldwide-share-halal-food-market-by-product/ (accessed on 15 May 2021).

6. Statista. Number of Product Launches with Halal Claims Worldwide in 2016, by Country. Available online: https: / /www.statista. com/statistics/1232367/global-number-of-product-launches-with-halal-claims-by-country/ (accessed on 15 May 2021).

7. Pew Research Center. The Global Religious Landscape A Report on the Size and Distribution of the World's Major Religious Groups as of 2010. Available online: https://assets.pewresearch.org/wp-content/uploads/sites/11/2014/01/global-religionfull.pdf (accessed on 5 May 2021).

8. Lipka, M.; Hackett, C. Why Muslims are the World's Fastest-Growing Religious Group. Available online: https: //www.pewresearch.org/fact-tank/2017/04/06/why-muslims-are-the-worlds-fastest-growing-religious-group/ (accessed on 21 May 2021).

9. Dinar Standard. State of the Global Islamic Economy Report, Thriving in Uncertainty-2020/2021; Dinar Standard: New York, NY, USA, 2020.

10. Krishnan, S.; Omar, C.M.C.; Zahran, I.; Syazwan, N.; Alyaa, S. The Awareness of Gen Z's toward Halal Food Industry. Management 2017, 7, 44-47.

11. Aziz, Y.A.; Chok, N.V. The Role of Halal Awareness, Halal Certification, and Marketing Components in Determining Halal Purchase Intention Among Non-Muslims in Malaysia: A Structural Equation Modeling Approach. J. Int. Food Agribus. Mark. 2012, 25, 1-23. [CrossRef]

12. De Boni, A.; Forleo, M.B. Italian halal food market development: Drivers and obstacles from experts' opinions. J. Islam. Mark. 2019, 10, 1245-1271. [CrossRef]

13. Thomson Reuters. State of the Global Islamic Economy 2013 Report. Available online: https://iccia.com/sites/default/files/ library / files/tr-state-of-islamic-economy-2013.pdf (accessed on 15 May 2021).

14. Ambali, A.R.; Bakar, A.N. People's Awareness on Halal food and Products: Potential Issues for Policy Makers. Procedia Soc. Behav. Sci. 2014, 121, 3-25. [CrossRef]

15. Laluddin, H.; Sikandar, S.; Haneef, S.; Saad, N.; Khalid, H. The Scope, Opportunities and Challenges of Halal Industry: Some Reflections. Int. J. Econ. Manag. Account. 2019, 27, 397-421.

16. Golnaz, R.; Zainalabidin, M.; Mad Nasir, S. Can Halal Be Sustainable? Study on Malaysian Consumers' Perspective. J. Food Prod. Mark. 2015, 21, 654-666.

17. Al-Ansi, A.; Olya, H.G.T.; Han, H. Effect of general risk on trust, satisfaction, and recommendation intention for halal food. Int. J. Hosp. Manag. 2019, 83, 210-219. [CrossRef]

18. GMTI (Mastercard-Crescent Rating Global Muslim Travel Index). Indonesia and Malaysia Take the Top Positions in the Fast-Growing Muslim Travel Market. Available online: https://www.mastercard.com/news/ap/en/newsroom/pressreleases/en/2019/april/mastercard-crescentrating-global-muslim-travel-index-gmti-2019-indonesia-and-malaysia-take-thetop-positions / (accessed on 20 May 2021).

19. Liu, Y.; Li, I.; Yen, S.; Sher, P.J. What Makes Muslim Friendly Tourism? An Empirical Study on Destination Image, Tourist Attitude and Travel Intention. Adv. Manag. Appl. Econ. 2018, 8, 27-43.

20. Vargas-Sánchez, A.; Moral-Moral, M. Halal tourism: State of the art. Tour. Rev. 2019, 74, 385-399. [CrossRef]

21. Ramankutty, N.; Mehrabi, Z.; Waha, K.; Jarvis, L.; Kremen, C.; Herrero, M.; Rieseberg, L.H. Trends in Global Agricultural Land Use: Implications for Environmental Health and Food Security. Annu. Rev. Plant Biol. 2018, 69, 789-815. [CrossRef] [PubMed]

22. Talib, M.S.A.; Hamid, A.B.A.; Zulfakar, M.H. Halal supply chain critical success factors: A literature review. J. Islam. Mark. 2015, 6, 44-71. [CrossRef]

23. Talib, M.S.A.; Hamid, A.B.A.; Ai Chin, T. Motivations and limitations in implementing halal food certification: A Pareto analysis Br. Food J. 2015, 117, 2664-2705. [CrossRef]

24. Abdullah, R.; Sabar, R.; Mustafar, M. Green Halal supply chain in Malaysian halal food companies: A conceptual framework. Int. J. Supply Chain. Manag. 2018, 7, 502-510.

25. Rejeb, A.; Rejeb, K.; Zailani, S. Are Halal Food Supply Chains Sustainable: A Review and Bibliometric Analysis. J. Foodserv. Bus. Res. 2021, 24, 554-595. [CrossRef]

26. Amicarelli, V.; Bux, C. Food waste in Italian households during the Covid-19 pandemic: A self-reporting approach. Food Secur. 2021, 13, 25-37. [CrossRef]

27. Bungeand, J.; Newman, J. Tyson Turns to Robot Butchers, Spurred by Coronavirus Outbreaks. Wall Str. J. 2020. Available online: https:/ / www.wsj.com/articles/meatpackers-covid-safety-automation-robots-coronavirus-11594303535 (accessed on 20 November 2021)

28. Dinar Standard. State of the Global Islamic Economy Report 2019/2020; Dinar Standard: New York, NY, USA, 2019.

29. Snyder, H. Literature review as a research methodology: An overview and guidelines. J. Bus. Res. 2019, 2014, 333-339. [CrossRef]

30. Torraco, R.J. Writing integrative literature reviews: Guidelines and examples. Hum. Resour. Dev. Rev. 2005, 4, 356-367. [CrossRef]

31. MacInnis, D.J. A framework for conceptual contributions in marketing. J. Mark. 2011, 75, 136-154. [CrossRef]

32. Whittemore, R.; Knafl, K. The integrative review: Updated methodology. J. Adv. Nurs. 2005, 52, 546-553. [CrossRef] [PubMed] 
33. Macke, J.; Sarate, J.A.R.; Domeneghini, J.; da Silva, K.A. Where do we go from now? Research framework for social entrepreneurship. J. Clean. Prod. 2018, 183, 677-685. [CrossRef]

34. Dillard, P.K.; Zuniga, J.A.; Holstad, M.A. An integrative review of the efficacy of motivational interviewing in HIV management. Patient Educ. Couns. 2017, 100, 636-646. [CrossRef] [PubMed]

35. Moher, D.; Liberati, A.; Tetzlaff, J.; Altman, D.G. Linee guida per il reporting di revisioni sistematiche e meta-analisi: Il PRISMA Statement. Evidence 2015, 7, e1000114.

36. Walsh, K. Qualitative research: Advancing the science and practice of hospitality. Cornell Hotel. Restaur. Adm. Q. 2003, 44, 66-74. [CrossRef]

37. van Eck, N.J.; Waltman, L. VOSviewer Manual: Manual for VOSviewer Version 1.6.17. Available online: https:/ /www.vosviewer. com/documentation/Manual_VOSviewer_1.6.17.pdf (accessed on 20 December 2021).

38. Sigala, M.; Kumar, S.; Donthu, N.; Sureka, R.; Joshi, Y. A bibliometric overview of the Journal of Hospitality and Tourism Management: Research contributions and influence. J. Hosp. Tour. Manag. 2021, 47, 273-288. [CrossRef]

39. Niñerola, A.; Sánchez Rebull, V.; Hernández-Lara, A.B. Tourism Research on Sustainability: A Bibliometric Analysis. Sustainability 2019, 11, 1377. [CrossRef]

40. Aluculesei, A.C.; Nistoreanu, P.; Avram, D.; Nistoreanu, B.G. Past and Future Trends in Medical Spas: A Co-Word Analysis. Sustainability 2021, 13, 9646. [CrossRef]

41. Page, M.J.; McKenzie, J.E.; Bossuyt, P.M.; Boutron, I.; Hoffmann, T.C.; Mulrow, C.D.; Shamseer, L.; Tetzlaff, J.M.; Akl, E.A.; Brennan, S.E.; et al. The PRISMA 2020 statement: An updated guideline for reporting systematic reviews. BMJ 2021, 372, 1-9.

42. Che Man, Y.B.; Aida, A.A.; Raha, A.R.; Son, R. Identification of pork derivatives in food products by species-specific polymerase chain reaction (PCR) for halal verification. Food Control 2007, 18, 885-889. [CrossRef]

43. Lever, J.; Miele, M. The growth of halal meat markets in Europe: An exploration of the supply side theory of religion. J. Rural. Stud. 2012, 28, 528-537. [CrossRef]

44. Rejeb, A.; Rejeb, K.; Zailani, S.; Treiblmaier, H.; Hand, K.J. Integrating the Internet of Things in the halal food supply chain: A systematic literature review and research agenda. Internet Things 2021, 13, 100361. [CrossRef]

45. Hew, J.J.; Wong, L.W.; Tan, G.W.H.; Ooi, K.B.; Lin, B. The blockchain-based Halal traceability systems: A hype or reality? Supply Chain. Manag. 2020, 25, 863-879. [CrossRef]

46. Surjandari, I.; Yusuf, H.; Laoh, E.; Maulinda, R. Designing a Permissioned Blockchain Network for the Halal Industry using Hyperledger Fabric with multiple channels and the raft consensus mechanism. J. Big Data 2021, 8, 10. [CrossRef]

47. Ali, M.H.; Chung, L.; Kumar, A.; Zailani, S.; Tan, K.H. A sustainable Blockchain framework for the halal food supply chain: Lessons from Malaysia. Technol. Forecast. Soc. Change 2021, 170, 120870. [CrossRef]

48. Alzeer, J.; Rieder, U.; Hadeed, K.A. Good agricultural practices and its compatibility with Halal standards. Trends Food Sci. Technol. 2020, 102, 237-241. [CrossRef]

49. Chanin, O. The Conceptual Framework for a Sustainable Halal SPA Business in the Gulf of Thailand. Int. J. Manag. Stud. 2016, 23, 83-95. [CrossRef]

50. Randeree, K. Challenges in halal food ecosystems: The case of the United Arab Emirates. Br. Food J. 2019, 121, 1154-1167. [CrossRef]

51. Nisha, N.; Iqbal, M. Halal Ecosystem: Prospect for Growth in Bangladesh. Int. J. Bus. Soc. 2017, 18, $205-222$.

52. Jalil, H.; Qamar, T. Developing Halal Compliante Critical Points (HCCP) for Halal Slaughtering System. J. Anim. Plant Sci. 2019, $29,1-5$.

53. Ahamat, H.; Rahman, N.A. Halal Food, Market Access and Exception to WTO Law: New Aspects Learned from IndonesiaChicken Products. Asian J. WTO Int. Health Law Policy 2018, 13, 2355-2373.

54. Shahdan, I.A.; Regenstein, J.M.; Shahabuddin, A.S.M.; Rahman, M.T. Developing control points for halal slaughtering of poultry. Poult. Sci. 2016, 95, 1680-1692. [CrossRef] [PubMed]

55. Ab Talib, M.S.; Abdul Hamid, A.B.; Chin, T.A. Can halal certification influence logistics performance? J. Islam. Mark. 2016, 7 , 461-475. [CrossRef]

56. Ab Talib, M.S.; Ai Chin, T.; Fischer, J. Linking Halal food certification and business performance. Br. Food J. 2017, 119, 1606-1618. [CrossRef]

57. Khan, S.; Haleem, A.; Khan, M.I.; Abidi, M.H.; Al-Ahmari, A. Implementing Traceability Systems in Specific Supply Chain Management (SCM) through Critical Success Factors (CSFs). Sustainability 2018, 10, 204. [CrossRef]

58. Prabowo, S.; Abd Rahman, A.; Ab Rahman, S.; Samah, A.A. Revealing factors hindering halal certification in East Kalimantan Indonesia. J. Islam. Mark. 2015, 6, 268-291. [CrossRef]

59. Hanzaee, K.H.; Ramezani, M.R. Intention to halal products in the world markets. Interdiscip. J. Res. Bus. 2011, 1, 1-7.

60. Khan, S.; Khan, M.I.; Haleem, A. Evaluation of barriers in the adoption of halal certification: A fuzzy DEMATEL approach. J. Model. Manag. 2019, 14, 153-174. [CrossRef]

61. Lada, S.; Tanakinjal, G.H.; Amin, H. Predicting intention to choose halal products using theory of reasoned action. Int. J. Islam. Middle East. Financ. Manag. 2009, 2, 66-76. [CrossRef]

62. National Research Council. Certifiably Sustainable? The Role of Third-Party Certification Systems; The National Academies Press: Washington, DC, USA, 2010. 
63. Dubé, F.N.; HaiJuan, Y.; Lijun, H. Halal Certification System as a Key Determinant of Firm Internationalisation in the Philippines and Malaysia. Asian Acad. Manag. J. 2016, 21, 73-88.

64. Haleem, A.; Khan, M.I.; Khan, S. Halal certification, the inadequacy of its adoption, modelling and strategising the efforts. $J$. Islam. Mark. 2020, 11, 384-404. [CrossRef]

65. Shafie, S.; Othman, M.N. Halal certification: An international marketing issues and challenges. In Proceedings of the International IFSAM 8th World Congress, Kuala Lampur, Malaysia, 28-30 September 2006.

66. Othman, B.; Shaarani, S.M.; Bahron, A. Evaluation of knowledge, halal quality assurance practices and commitment among food industries in Malaysia. Br. Food J. 2016, 118, 2033-2052. [CrossRef]

67. Nurulhuda, N.; Nor Laila, M.N.; Zaina, S. Strategic Approach to Halal Certification System: An Ecosystem Perspective. Procedia Soc. Behav. Sci. 2014, 121, 79-95.

68. Halal Accreditation Agency. Halal Regulations by Country. Available online: https://english.hak.gov.tr/international-relations/ country-based-regulations/europe (accessed on 22 July 2021).

69. Borzooei, M.; Asgari, M. Discovering perceptions of Muslim consumers toward the ICRIC Halal logo. J. Islam. Account. Bus. Res. 2016, 7, 304-317. [CrossRef]

70. Abd Rahman, A.; Singhry, H.B.; Hanafiah, M.H.; Abdul, M. Influence of perceived benefits and traceability system on the readiness for Halal Assurance System implementation among food manufacturers. Food Control 2017, 73, 1318-1326. [CrossRef]

71. Halamului. List of Approved Foreign Halal Certification Bodies. Available online: https://www.halalmui.org/images/stories/ pdf/LSH/LSHLN-LPPOM\%20MUI.pdf (accessed on 22 July 2021).

72. Amicarelli, V.; Bux, C. Halal certification and Healthy Lifestyles. In Encyclopedia of Quality of Life and Well-Being Research; Maggino, F., Ed.; Springer: Cham, Switzerland, 2021.

73. van der Spiegel, M.; van der Fels-Klerx, H.J.; Sterrenburg, P.; van Ruth, S.M.; Scholtens-Toma, I.M.J.; Kok, E.J. Halal assurance in food supply chains: Verification of halal certificates using audits and laboratory analysis. Trends Food Sci. Technol. 2012, 27, 109-119. [CrossRef]

74. Tieman, M. Halal Supply Chain Certification: The Next Frontier in Halal Certification? Islam Civiliz. Renew. 2018, 9, 233-236. [CrossRef]

75. Ahmed, W.; Najmi, A.; Faizan, H.M.; Ahmed, S. Consumer behaviour towards willingness to pay for Halal products: An assessment of demand for Halal certification in a Muslim country. Br. Food J. 2019, 121, 492-504. [CrossRef]

76. Wannasupchue, W.; Mohamad, S.F.; Ishak, F.A.C.; Ungku Zainal Abidin, U.F. Challenges to obtain halal certification among restaurants in northeast Thailand. J. Islam. Mark. 2021. Vol. ahead-of-print. [CrossRef]

77. White, G.R.T.; Samuel, A. Fairtrade and Halal Food Certification and Labeling: Commercial Lessons and Religious Limitations. J. Macromark. 2016, 36, 388-399. [CrossRef]

78. Ab Talib, M.S.; Md Sawari, S.S.; Abdul Hamid, A.B.; Ai Chin, T. Emerging Halal food market: An Institutional Theory of Halal certificate implementation. Manag. Res. Rev. 2016, 39, 987-997. [CrossRef]

79. Zulfakar, M.H.; Jie, F.; Chan, C. Halal food supply chain integrity: From a literature review to a conceptual framework. In Proceedings of the 10th ANZAM Operations, Supply Chain and Services Management Symposium, Melbourne, Australia, 14-15 June 2012.

80. Tieman, M. Halal clusters. J. Islam. Mark. 2015, 6, 2-21. [CrossRef]

81. Kurth, L.; Glasbergen, P. Serving a heterogeneous Muslim identity? Private governance arrangements of halal food in the Netherlands. Agric. Hum. Values 2017, 34, 103-118. [CrossRef]

82. Batu, A.; Regenstein, J.M. Halal food certification challenges and their implications for Muslim societies worldwide. Turk. Stud. 2014, 9, 111-130. [CrossRef]

83. Escanciano, C.; Santos-Vijande, M.L. Implementation of ISO-22000 in Spain: Obstacles and key benefits. Br. Food J. 2014, 116, 1581-1599. [CrossRef]

84. Rafiki, A.; Abdul Wahab, K. The human capital and the obtainment of halal certification. J. Islam. Mark. 2016, 7, 134-147. [CrossRef]

85. Abdul Rahim, N.R.; Abdullah, I.; Yahya, N.A.; Awang, M.N.; Muhammad, S.Z.; Ahmad Sabri, S.; Ahmad, N.N. Negotiation of needs towards halal talents sustainability. J. Islam. Mark. 2020, 13, 20-44. [CrossRef]

86. Psomas, E.L.; Fotopoulos, C.V.; Kafetzopoulos, D.P. Motives, difficulties and benefits in implementing the ISO 14001 environmental management system. Manag. Environ. Qual. Int. J. 2011, 22, 502-521. [CrossRef]

87. Vanany, I.; Maarif, G.A.; Soon, J.M. Application of multi-based quality function deployment (QFD) model to improve halal meat industry. J. Islam. Mark. 2019, 10, 97-124. [CrossRef]

88. Sawari, S.S.; Ghazali, M.S.; Ibrahim, M.B.; Mustapha, N.I. Evidence Based Review on the Effect of Islamic Dietary Law Towards Human Development. Mediterr. J. Soc. Sci. 2015, 6, 136-141.

89. Katuz, N. The application of blockchain for halal product assurance: A systematic review of the current developments and future directions. Int. J. Adv. Trends Comput. Sci. Eng. 2019, 8, 1893-1902.

90. Rana, R.L.; Tricase, C.; De Cesare, L. Blockchain technology for a sustainable agri-food supply chain. Br. Food J. 2021, 123, 3471-3485. [CrossRef]

91. European Environmental Agency. Blockchain and the Environment. Available online: https://www.eea.europa.eu/publications / blockchain-and-the-environment (accessed on 21 December 2021). 
92. Adamashvili, N.; Gallo, C.; Rana, R.L.; Faccilongo, N. Blockchain Technology-The Tool for Revolutionize the Agri-Food Supply Chain. In Proceedings of the Dynamics and Recent Trends of Vary Industries in Eu and Georgia: Icts Adoption in Supply Chain Management, Tiblisi, Georgia, 17-19 October 2018.

93. Chandra, G.; Liaget, I.M.; Sharma, B. Blockchain Redefining: The Halal Food Sector. In Proceedings of the 2019 Amity International Conference on Artificial Intelligence (AICAI), Dubai, United Arab Emirate, 4-6 February 2019.

94. Casino, F.; Dasaklis, T.K.; Constantinos, P. A systematic literature review of blockchain-based applications: Current status, classification and open issues. Telemat. Inform. 2019, 36, 55-81. [CrossRef]

95. Antonucci, F.; Figorilli, S.; Costa, C.; Pallottino, F.; Raso, L.; Menesatti, P. A review on blockchain applications in the agri-food sector. J. Sci. Food Agric. 2019, 99, 6129-6138. [CrossRef] [PubMed]

96. Tan, A.; Gligor, D.; Ngah, A. Applying Blockchain for Halal food traceability. Int. J. Logist. Res. Appl. 2020. Vol. ahead-of-print. [CrossRef]

97. Köhler, S.; Pizzol, M. Technology assessment of blockchain-based technologies in the food supply chain. J. Clean. Prod. 2020, 269, 122193. [CrossRef]

98. Foodwatch. The Foodwatch Platform. Available online: https:/ / foodwatch.dm.gov.ae (accessed on 17 June 2021).

99. Burton, S. Automation is Happening-Don't Miss the Boat. Food Saf. Tech. 2018. Available online: https://foodsafetytech.com/ column/automation-is-happening-dont-miss-the-boat/ (accessed on 15 November 2021).

100. Ab, R.M.; Manzouri, M.; Ch, R.; Zain Ch, M. Environmental concern in managing halal food supply chain. Am. J. Environ. Sci. 2013, 9, 240-246.

101. Al Halaseh, L.; Sundarakani, B. Study on quality attributes of halal food supply chain. Int. J. Logist. Econ. Glob. 2012, 4, 20-34. [CrossRef]

102. Adamashvili, N.; State, R.; Tricase, C.; Fiore, M. Blockchain-Based Wine Supply Chain for the Industry Advancement. Sustainability 2021, 13, 13070. [CrossRef]

103. Thamagasorn, M.; Pharino, C. An analysis of food waste from a flight catering business for sustainable food waste management: A case study of halal food production process. J. Clean. Prod. 2019, 228, 845-855. [CrossRef]

104. Manzouri, M.; Ab-Rahman, M.N.; Zain, C.R.C.M.; Jamsari, E.A. Increasing production and eliminating waste through lean tools and techniques for halal food companies. Sustainability 2014, 6, 9179-9204. [CrossRef]

105. Kumar, N.M.; Chopra, S.S. Blockchain Technology for Tracing Circularity of Material Flows. In Proceedings of the 10th International Conference of the International Society for Industrial Ecology (ISIE 2019), Beijing, China, 7-11 July 2019.

106. Rejeb, A.; Keogh, J.G.; Zailani, S.; Treiblmaier, H.; Rejeb, K. Blockchain Technology in the Food Industry: A Review of Potentials, Challenges and Future Research Directions. Logistics 2020, 4, 27. [CrossRef] 